УДК 612.34:577.175.72:577.171.4

\title{
THE ROLE OF ENERGY METABOLISM IN AMINO ACID STIMULATED INSULIN RELEASE IN PANCREATIC $\beta$-HC9 CELLS
}

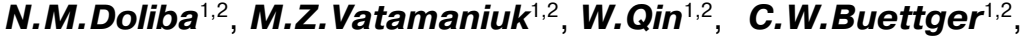 \\ H.W.Collins ${ }^{1,2}$, S.L.Wehrli ${ }^{3}$, F.M.Matschinsky ${ }^{1,2}$ \\ ${ }^{1}$ Department of Biochemistry and Biophysics \\ ${ }^{2}$ Institute for Diabetes, Obesity and Metabolism, University of Pennsylvania \\ School of Medicine, Philadelphia, Pennsylvania 19104 \\ ${ }^{3}$ Children's Hospital of Philadelphia, Philadelphia, Pennsylvania 19104 \\ e-mail: nicolai@mail.med.upenn.edu
}

Fuel stimulation of insulin secretion from pancreatic $\beta$-cells is thought to be mediated by metabolic coupling factors that are generated by energized mitochondria, including protons, adenine nucleotides and perhaps certain amino acids, as for instance aspartate, glutamate or glutamine. The goal of the present study was to evaluate the role of such factors when insulin release (IR) is stimulated by glucose or amino acids (AA), alone or combined, using ${ }^{31} \mathrm{P}-,{ }^{23} \mathrm{Na}-$ and ${ }^{1} \mathrm{H}-\mathrm{NMR}$-technology, respirometry and biochemical analysis to study the metabolic events that occur in continuously superfused mouse $\beta-\mathrm{HC} 9$ cells contained in agarose beads and enhanced by the phosphodiesterase inhibitor IBMX. Exposing $\beta$-HC9 cells to high glucose or $3.5 \mathrm{mM}$ of a physiological mixture of 18 AA plus $2 \mathrm{mM}$ glutamine $(\mathrm{Q})$ caused a marked stimulation of insulin secretion associated with increased oxygen consumption $\left(\mathrm{V}_{\mathrm{O} 2}\right)$, c-AMP release and phosphorylation potential (P-potential) as evidenced by higher Phosphocreatine $(\mathrm{PCr})$ and lower $\mathrm{P}_{i}$ peak areas of ${ }^{31} \mathrm{P}$ NMR spectra. Diazoxide blocked stimulation of IR completely suggesting involvement of $\mathrm{K}_{\text {ATP }}$ channels in this process. However, levels of [MgATP] and [MgADP] which regulate channel activity changed only slowly and little while the rate of insulin release increased fast and very markedly. The involvement of other candidate coupling factors was therefore considered. High glucose or AAM $+\mathrm{Q}$ increased intracellular $\mathrm{pH}$. The availability of temporal $\mathrm{pH}$ profiles allowed the precise computation of the phosphate potential $\left(A T P / P_{i} \times A D P\right)$ in fuel stimulated IR. Intracellular $\mathrm{Na}^{+}$levels were greatly elevated by $A A M+Q$. However, glutamine alone or together with 2-amino-2-norbornanecarboxylic acid $(\mathrm{BCH}$, which activates glutamate dehydrogenase) decreased $\beta$-cell $\mathrm{Na}$ levels. Stimulation of $\beta$-cells by glucose in the presence of $A A M+Q(0.5 \mathrm{mM})$ was associated with rising cellular concentrations of glutamate, glutamine and strikingly lower aspartate levels. Methionine sulfoximine (MSO), an inhibitor of glutamine synthetase, blocked the glucose enhancement of $A M M+Q$ induced IR and associated changes in glutamine and aspartate but did not prevent the accumulation of glutamate. The results 
of this study demonstrate again that an increased phosphate potential and a functional $\mathrm{K}_{\text {ATP }}$ channel are essential for metabolic coupling during fuel stimulated insulin release but illustrate that determining the identity and relative importance of all participating coupling factors and second messengers remains a challenge largely unmet.

Key words: amino acids, energy metabolism, oxygen consumption, sodium, mitochondria.

\title{
РОЛЬ ЕНЕРГЕТИЧНОГО МЕТАБОЛІЗМУ В СЕКРЕЦІї ІНСУЛІНУ, СТИМУЛЬОВАНІЙ АМІНОКИСЛОТАМИ У $\beta$-НС9 КЛІТИНАХ ПІДШЛУНКОВОї ЗАЛОЗИ
}

\author{
М.Доліба $^{1,2}$, М.Ватаманюк ${ }^{1,2}$, В.Квін ${ }^{1,2}$, К.Буетгер ${ }^{1,2}$, \\ Х.Коллінз ${ }^{1,2}$, С.Верлі ${ }^{3}$, Ф.Мачинський ${ }^{1,2}$, \\ ${ }^{1}$ Відділ біохімії і біофізики \\ ${ }^{2}$ Інститут діабету, ожиріння і метаболізму медичної школи \\ Пенсільванського університету, Філадельфія, Пенсільванія 19104 \\ ЗФіладельфійський дитячий госпіталь, Філадельфія, Пенсільванія 19104 \\ e-mail: nicolai@mail.med.upenn.edu
}

Метаболічна стимуляція секреції інсуліну панкреатичними $\beta$-клітинами опосередковується через метаболічні спряжуючі фактори, що генеруються енергізованими мітохондріями, включаючи протони, аденілові нуклеотиди та, можливо, деякі амінокислоти (аспартат, глутамат і глютамін). Метою даного дослідження було вивчення ролі цих факторів за стимуляції секреції інсуліну глюкозою та амінокислотами. Метаболічні процеси у суперфузованих $\beta$-клітинах ( $\beta$-НС9) вивчали за допомогою методів ${ }^{31} \mathrm{P}$-, ${ }^{23} \mathrm{Na}-\mathrm{i}{ }^{1} \mathrm{H}$-ядерно-магнітно-резонансної спектроскопії та полярографії. Висока концентрація глюкози (30 мМ) та фізіологічна суміш 19-ти амінокислот (3.5 мМ) викликали виразну стимуляцію секреції інсуліну, яка супроводжувалася підвищенням поглинання кисню, звільненням ц-АМФ та підвищенням енергетичного потенціалу клітин в основному внаслідок зростання кількості фосфокреатину та зменшення неорганічного фосфату. Активатор $\mathrm{K}_{\text {АтФ }}$ каналів, диазоксид, повністю блокував стимуляцію секреції інсуліну амінокислотами, що вказує на участь цих каналів у регуляції секреції інсуліну. Оскільки рівні Mg-АТФ і Mg-АДФ, які регулюють активність $\mathrm{K}_{\text {АтФ }}$ каналу, достовірно не змінювалися під час стимуляції секреції інсуліну, вивчали також роль інших спряжуючих факторів. Зокрема, висока концентрація глюкози та суміш амінокислот підвищували внутрішньоклітинний $\mathrm{pH}$, що, можливо, призводить до підвищення спорідненості $\mathrm{K}_{\text {АтФ }}$ каналу до АТФ. У даній роботі також протестована гіпотеза Maechler and Wollheim (1999), яка вказує на роль глутамату як вторинного месенджера в секреції інсуліну. Стимуляція секреції інсуліну глюкозою у присутності суміші амінокислот дійсно супроводжувалася підвищенням рівня цитоплазматичної концентрації глутамату, глютаміну та виразним зменшенням концентрації аспартату. Однак застосування специфічних інгібіторів метаболізму цих субстратів вказує на те, що секреція інсуліну не завжди спряжена з підвищенням рівня глутамату. Тому цей субстрат є лише індикатором метаболізму, але не вторинними месенджером у регуляції секреції інсуліну. Результати дослідження вказують на те, що АТФ та $\mathrm{K}_{\text {АТP }}$ канали $€$ критичними спряжуючими 
факторами в секреції інсуліну. Однак залишається невідомим фактор, який призводить до підвищення спорідненості цих каналів до АТФ за стимуляції секреції інсуліну в $\beta$-клітинах.

Ключові слова: амінокислоти, енергетичний обмін, поглинання кисню.

\section{INTRODUCTION}

It is considered to be that the metabolism of amino acids contributes to the maintainance of citric acid cycle intermediates in the $\beta$-cell, a process termed anaplerosis, and considered to be important for insulin release (IR). Various transaminases and glutamate dehydrogenase $(\mathrm{GDH})$ initiate amino acid degradation resulting in transdeamination that funnels amino acids into intermediatory metabolism of the pancreatic $\beta$-cell. The activity of the transamination process is influenced by the energy status of the cell and is controlled by the ambient glucose level [16]. The glucose level also controls glutaminolysis, i.e. the catabolism of glutamine which influences IR. Glutaminase, which initiates glutaminolysis is a mitochondrial enzyme as is GDH [13]. Glutamine, the substrate for glutaminolysis, enters the cell via $\mathrm{Na}^{+}$dependent and independent transport across the cell membrane, reaches the mitochondrial matrix by a specific carrier system and is then deaminated by glutaminase to glutamate. Glutamate in turn serves as a substrate for several enzymes: 1) aminotransferases which react with various $\alpha$-ketoacids generating $\alpha$-ketoglutarate; 2 ) glutamate decarboxylase which produces $\gamma$-aminobutyrate; and 3) $\mathrm{GDH}$ which generates $\alpha$-ketoglutarate, $\mathrm{NAD}(\mathrm{P}) \mathrm{H}$ and $\mathrm{NH}_{4}^{+}$. The classical view of the mechanism of the secretory effect of amino acids is that they readily fuel mitochondrial metabolism leading to increased ATP production and a higher ATP/ADP ratio. The increased energy potential results in inhibition of $\mathrm{K}_{\text {ATP }}$ channels and activation of voltagedependent calcium channels, which then triggers insulin release via elevated $\mathrm{Ca}^{2+}$. One hypothesis postulates that the flux through GDH may also be directed toward glutamate formation and that glutamate, released from mitochondria, acts as a metabolic coupling factor in glucose-induced insulin exocytosis [36]. However, the experiments of another group [35] do not support this view. The authors [35] failed to observe an increase in the glutamate levels during stimulation of insulin release from pancreatic islets by glucose, leucine, succinic acid methyl ester and $\alpha$-ketoisocaproic acid and thus, suggest the traditional idea that insulin release is associated with flux through GDH in the direction of $\alpha$-ketoglutarate. Li et al. [31] exploring the same issue hypothesized that glutamine generated by glutamine synthetase may act directly as a metabolic messenger in stimulussecretion coupling in pancreatic $\beta$-cells. Because $\beta$-HC9 cells increase insulin release (in contrast to islets) and oxygen consumption when stimulated with an amino acids and are a homogeneous population that is easily expanded, we used this cell line in conjunction with ${ }^{31} \mathrm{P},{ }^{23} \mathrm{Na}$ and ${ }^{1} \mathrm{H}$ NMR-technology, respirometry and biochemical analysis to elucidate metabolism of amino acids and particularly of glutamine and glutamate in continuously superfused insulin secreting $\beta$-HC9. The results suggest that glutamine is the major factor in the amino acid-induced elevation of the phosphorylation potential, oxygen consumption and insulin release of $\beta$-HC9 cells. The levels of intracellular glutamine and glutamate rise during glucose-stimulated insulin release, while aspartate falls. However the changes in glutamate levels in $\beta$-cells do not correlate with glucose stimulated insulin release in the presence of methionine sulfoximine (MSO), an inhibitor of glutamine synthetase. Thus the results suggest that glutamine plays an important, but not an independent primary triggering role in the stimulus-secretion coupling. 


\section{RESEARCH DESIGN AND METHODS}

General Procedures. The $\beta$-HC9 cell line was obtained from Dr. D. Hanahan. Cells were maintained in Dulbecco's modified Eagles's medium (DMEM) with 15\% fetal calf serum and $24 \mathrm{mM}$ glucose. $\beta$-HC9 cells of passages $22-28$ were used in this study. Cells were supplemented with $25 \mathrm{mM}$ creatine $48 \mathrm{~h}$ before the experiment in order to better visualize the phosphocreatine peak by ${ }^{31} \mathrm{P}$ NMR spectroscopy. Creatine loading did not have an effect on insulin release or oxygen consumption of superfused $\beta-\mathrm{HC} 9$ cells. The cellular protein content was measured by the Lowry method [33].

Formation of beads. Cells were placed in agarose beads (bead size: $800-$ $1000 \mu \mathrm{m} ; 2000-2500$ beads $/ \mathrm{cm}^{3}$ ), to maintain them in a stable environment and prevent their escaping from the perifusion system [11]. Briefly, cells were suspended in $1 \mathrm{ml}$ Krebs-Ringer-Bicarbonate buffer containing (in $\mathrm{mM}$ ): $\mathrm{NaCl}-114, \mathrm{KCl}-5$, $\mathrm{NaHCO}_{3}-24, \mathrm{NaH}_{2} \mathrm{PO}_{4}-1, \mathrm{MgCl}_{2} \times 6 \mathrm{H}_{2} \mathrm{O}-1$, Creatine $-25, \mathrm{CaCl}_{2}-2.2$, Hepes -10 $(\mathrm{pH}=7.4)$ and $3 \mathrm{mM}$ glucose. Cells suspended in this buffer were then added to $1 \mathrm{ml}$ of $6 \%$ agarose (Sigma type VII, low gelling temperature) and mixed at $37^{\circ} \mathrm{C}$. This suspension was then decanted into $50 \mathrm{ml}$ of paraffin oil $\left(37^{\circ} \mathrm{C}\right)$ and stirred continuously. The interaction (difference in surface tension) of the oil and agarose caused bead formation. Beads were cooled to $10^{\circ} \mathrm{C}$ by adding ice to the water bath under continuous stirring for $5 \mathrm{~min}$ to allow them to become firm and to maintain their shape. The beads were irregularly shaped with an average size of $1 \mathrm{~mm}$ diameter, as was determined by phase contrast microscopy (Nikon TMS). Cell containing beads were suspended in buffer, and washed several times.

Perifusion apparatus for oxygen consumption experiments. Cell containing beads were placed between two $\sim 100 \mu \mathrm{m}$ filters in a flow through column (Bio Rad). Oxygen partial pressure was recorded polarographically with Clark-type oxygen electrodes placed in inflow and outflow. The perifusion medium was maintained at $37^{\circ} \mathrm{C}$ using a water bath. Note that all perifusion media contained $0.1 \mathrm{mM}$ IBMX because the increase of insulin release of $\beta$-HC9 cells stimulated by glucose or amino acids in its absence is only small. The oxygen consumption rate was calculated from the flow rate, and the difference in the oxygen partial pressures between the influent and the effluent using the Bunsen absorption coefficient [53]. The effluent from the cells was collected for insulin measurements.

Perifusion apparatus for NMR experiments. Cell containing beads were placed in a $10 \mathrm{~mm}$ diameter glass NMR tube and maintained in place by a filter $(100 \mu \mathrm{m}$ pore size) [10]. Each NMR sample contained approximately $1.5 \mathrm{ml}$ of the beads suspended in $1 \mathrm{ml}$ buffer (20 $\mathrm{mg}$ of cell protein). The cells and the capillary tube containing methylene diphosphonate (MDP) and $\mathrm{NaCl}$ with disprosium standards were placed within the sensitive volume of the NMR coil. The perifusion medium contained (in $\mathrm{mM}$ ): $\mathrm{NaCl}-114, \mathrm{KCl}-5, \mathrm{NaHCO}_{3}-24, \mathrm{NaH}_{2} \mathrm{PO}_{4}-1, \mathrm{MgCl}_{2} \times 6 \mathrm{H}_{2} \mathrm{O}-1$, Creatine $-25, \mathrm{CaCl}_{2}-2.2$, Hepes $-10(\mathrm{pH}=7.4)$ and was equilibrated with $95 \% \mathrm{O}_{2}, 5 \% \mathrm{CO}_{2}$ and was maintained at $37^{\circ} \mathrm{C}$ using a water bath. The temperature in the probe was also maintained by the internal variable temperature controller. The transfer lines were insulated. The buffer was introduced through an in-flow line (at $2.7 \mathrm{ml} / \mathrm{min}$ ). A suction line, placed above the beads removed the superfusate which was not recirculated.

${ }^{31} \mathbf{P}$ NMR methods. The ${ }^{31} \mathrm{P}$ NMR measurements were performed with a Avance DMX-400 spectrometer at $162 \mathrm{MHz} .{ }^{31} \mathrm{P}$ NMR spectra were acquired consecutively in 5 minute periods (500 transients) for up to 8 hours without proton decoupling (because the resonances are broad and the ${ }^{31} \mathrm{P}-,{ }^{1} \mathrm{H}$-couplings are relatively small $\left(3-12 \mathrm{~Hz}\right.$ ). The following conditions were used: pulse width $36^{\circ}$, sweep width $13 \mathrm{kHz}$, $16 \mathrm{~K}$ data points, repetition time $0.6 \mathrm{~s}$. Free induction decays (FID's) were processed 
with a Lorentz-Gauss window function for resolution enhancement (Bruker parameters: line broadening $(\mathrm{LB})=-8$, maximum of the Gaussian function $(\mathrm{GB})=0.003$ ).

${ }^{23} \mathrm{Na}$ NMR methods. Intracellular $\mathrm{Na}^{+}$was determined using thulium-DOTP (3.5 $\mathrm{mM}$ ) as shift reagent. The following conditions were used: pulse width $90^{\circ}$, sweep width $6.3 \mathrm{kHz}, 4 \mathrm{~K}$ data points, repetition time $0.325 \mathrm{~s}$. $3 \mathrm{~Hz}$ line broadening $(\mathrm{LB}=3)$ was applied.

Calculation of intracellular $\mathbf{p H}$. Intracellular $\mathrm{pH}$ was calculated using ${ }^{31} \mathrm{P}$ data according to [50]:

$\mathrm{pH}=6.75+\log (\Delta-3.27 / 5.69-\Delta)$, where: $\Delta$ is the chemical shift difference between signal of inorganic phosphate and phosphocreatine.

Calculation of intracellular ADP. The parameters of the creatine kinase equilibrium reaction were used to calculate the concentration of free intracellular ADP [20]:

$\mathrm{Cr}-\mathrm{P}^{2-}+\mathrm{MgADP}^{-}+\mathrm{H}^{+} \rightarrow \mathrm{Cr}+\mathrm{MgATP}^{2-}$

$[\mathrm{MgADP}] /[\mathrm{MgATP}]=([\mathrm{Cr}] / \mathrm{PCr}]-1) \times 10^{\mathrm{pH}} / \mathrm{K}$ where: $\mathrm{K}=1.66 \times 10^{9} \mathrm{~mol}^{-1}$.

Insulin and c-AMP measurments. Insulin content in efflux samples was measured by radioimmunoassay with charcoal separation [23]. Rat insulin from Linco Research served as standard and Miles anti-insulin antibody from ICN was the primary antibody. The C-AMP assay was performed according to the radioimmunoassay method of Albano and Barnes [1] using the Biotrak c-AMP ${ }^{125}$ ] assay system from Amersham Pharmacia Biotech.

Statistical Analysis. In appropriate cases, significant differences between groups were determined by one-way analysis of variance (ANOVA) with post hoc analysis using Dunnetts multiple-comparison test. Values of $P \leq 0.05$ were accepted as significant. In some instances typical results are presented for clarity of the temporal profiles $(n=3-5)$ and the statistical data with comparisons between the different groups are presented in Table 1.

\section{RESULTS}

Glutamine and Pi are two critical factors which affect amino acid-stimulated insulin release in $\beta$-HC9 cells. Figure 1 (panel $A$ and $B$ ) presents the results of continuous measurements of insulin and c-AMP release and oxygen consumption by perifused $\beta-\mathrm{HC} 9$ cells in response to stimulation with low $(3 \mathrm{mM})$ and high $(30 \mathrm{mM})$ glucose followed by addition of a physiological $3.5 \mathrm{mM}$ mixture of 18 amino acids (in $\mathrm{mM}$ : alanine 0.44 , arginine 0.19 , aspartate 0.038 , citrulline 0.094 , glutamate 0.12 , glycine 0.30 , histidine 0.077 , isoleucine 0.094 , leucine 0.16 , lysine 0.37 , methionine 0.05 , ornithine 0.70 , phenylalanine 0.08 , proline 0.35 , serine 0.57 , threonine 0.27 , tryptophan 0.073 , valine 0.20 ) plus $2 \mathrm{mM}$ glutamine (AAM $+\mathrm{Q}$ ). Comparable to isolated pancreatic islets $[9,22,24], \beta-\mathrm{HC}$ cells responded to increasing levels of glucose by enhancing insulin and c-AMP release and oxygen consumption. However, in contrast to islets, $\beta$-HC9 cells respond to AAM $+Q$ by a burst in insulin release. $\mathrm{AAM}+\mathrm{Q}$ also elevated cyclic-AMP release and oxygen consumption. Glucose or 2-amino-bicyclo-norbonane carboxylic acid $(\mathrm{BCH})$, a non-metabolized leucine analogue and allosteric activator of glutamate dehydrogenase $(\mathrm{GDH},(49)$ did not further increase hormone releases in $\beta$ - $\mathrm{HC}$ cells in the presence of AAM + Q suggesting that a maximum rate of hormone release had been reached. It is noteworthy, that glucose in the presence of $A A M+Q$ influenced oxygen consumption and c-AMP only slightly. The uncoupling of respiration and oxidative phosphorylation by FCCP $(5 \mu \mathrm{M})$ blocked insulin and c-AMP release and markedly increased oxygen consumption indicating that respiration and oxidative phosphorylation are well coupled in this preparation and that both c-AMP and insulin release require enhanced ATP production. 


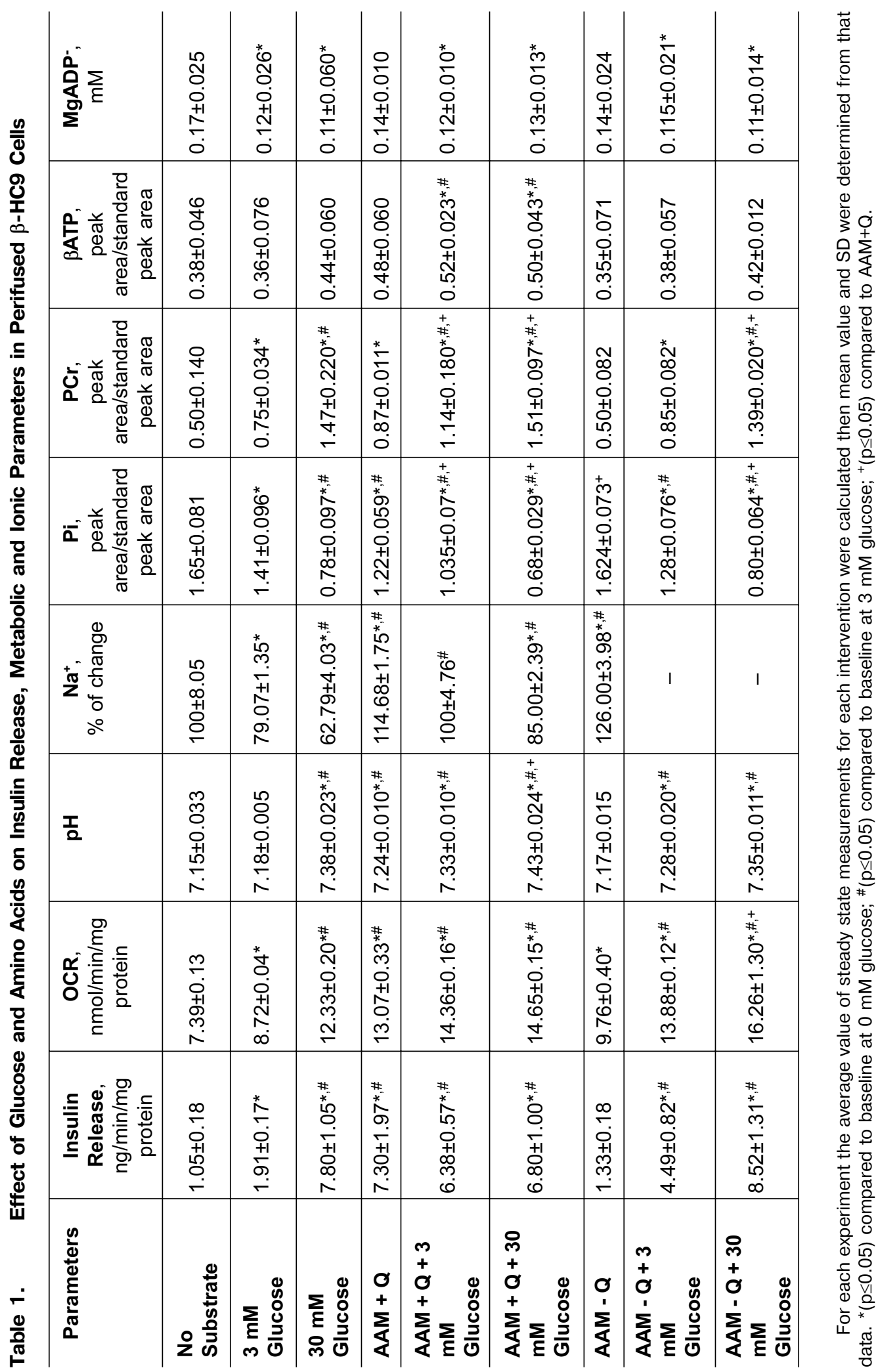


A
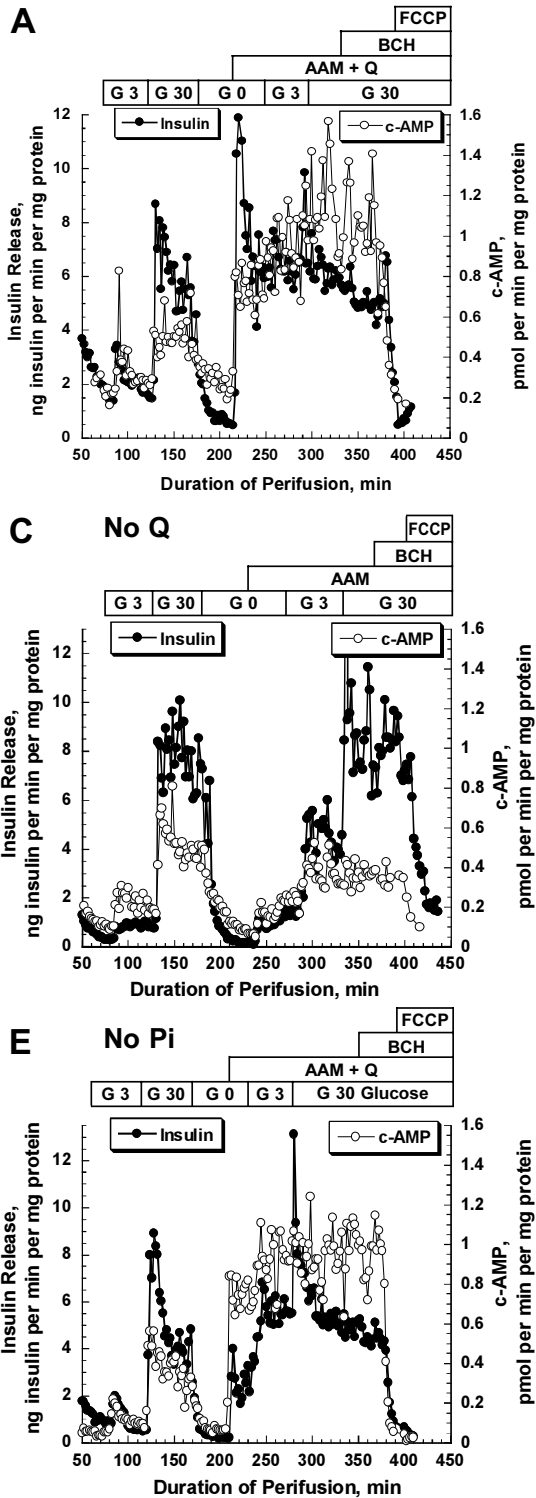

B
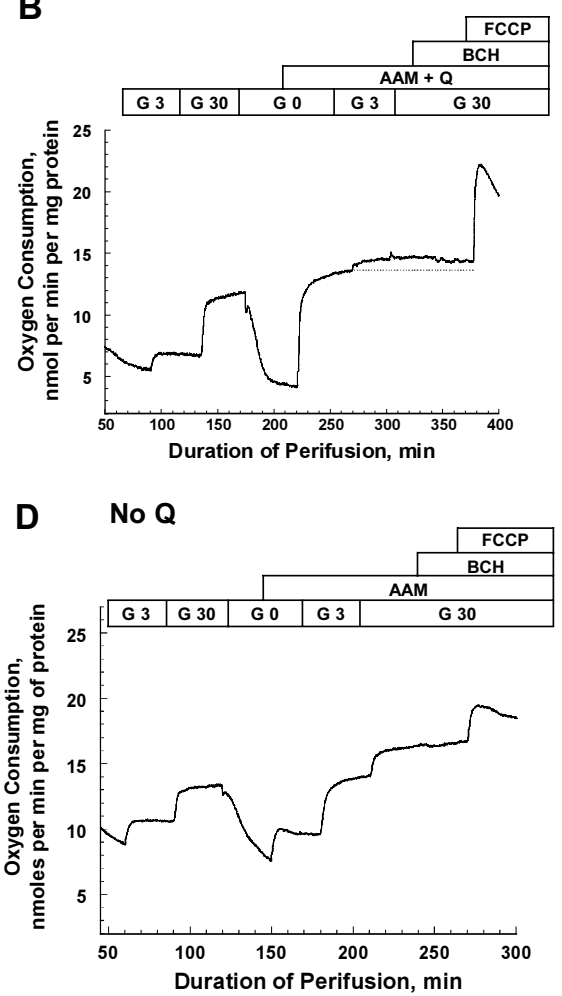

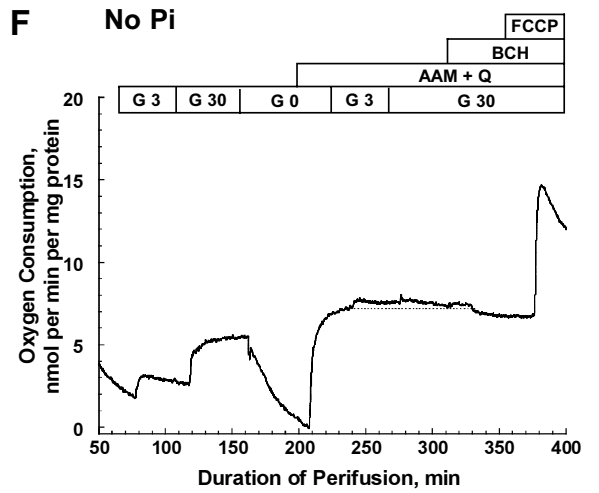

Fig. 1. Insulin and c-AMP release and oxygen consumption of perifused $\beta-\mathrm{HC}$ cells. $\beta$-HC9 cells were embedded in agarose beads and placed into a $1 \times 2 \mathrm{~cm}$ column which allowed perifusion of cells at a rate of approx $2 \mathrm{ml} / \mathrm{min}$. Clark oxygen electrodes were used to measure the arteriovenous (AV) difference of $\mathrm{O}_{2}$ to calculate the respiratory rate. Samples from the outflow were collected every 2 min to measure insulin content in all and c-AMP content in selected experiments. Panel A and B show insulin, c-AMP and oxygen consumption upon stimulation with glucose and the complete amino acid mixture. Panel C and D: Glutamine was removed from the amino acid mixture. Panel E and F: Cells were perifused without $\mathrm{Pi}$.

Each curve represents a mean of 3-5 experiments for insulin release and oxygen consumption but single or means of 2 experiments for c-AMP release. See Table 1 for statistical information

The omission of glutamine from the perifusate reduced AAM-stimulated insulin and C-AMP release (Fig. 1, panel C) and oxygen consumption (Fig. 1, panel D). Low and high glucose in the presence of AAM without glutamine (AAM-Q) greatly increased insulin release and oxygen consumption. The cyclic-AMP response was significantly blunted when glutamine was absent from the medium. The omission of Pi from the 
$A A M+Q$ mixture reduced $A A$-stimulated insulin release (Fig. 1E) similarly to leaving out glutamine but did not affect c-AMP release or AAM + Q-stimulated oxygen consumption (Fig. 1F). In fact the respiratory profiles of Figure $1 \mathrm{~B}$ and $1 \mathrm{~F}$ are virtually the same. Low glucose $(3 \mathrm{mM})$ further increased insulin release and high glucose $(30 \mathrm{mM})$ produced a rapid increase of insulin release that was not sustained. $\mathrm{BCH}$ was ineffective under these conditions. However, glutamine alone was not sufficient to support sustained insulin release in this $\beta$-cell line (Fig. 2). In contrast, glutamine with $\mathrm{BCH}$ (Fig. 2A) or glucose (Fig. 2C) greatly increased insulin release indicating the effects of these substances are interdependent. Glutamine alone stimulated oxygen consumption and $\mathrm{BCH}$ (panel B), low and high glucose (panel D) further increased oxidative metabolism.
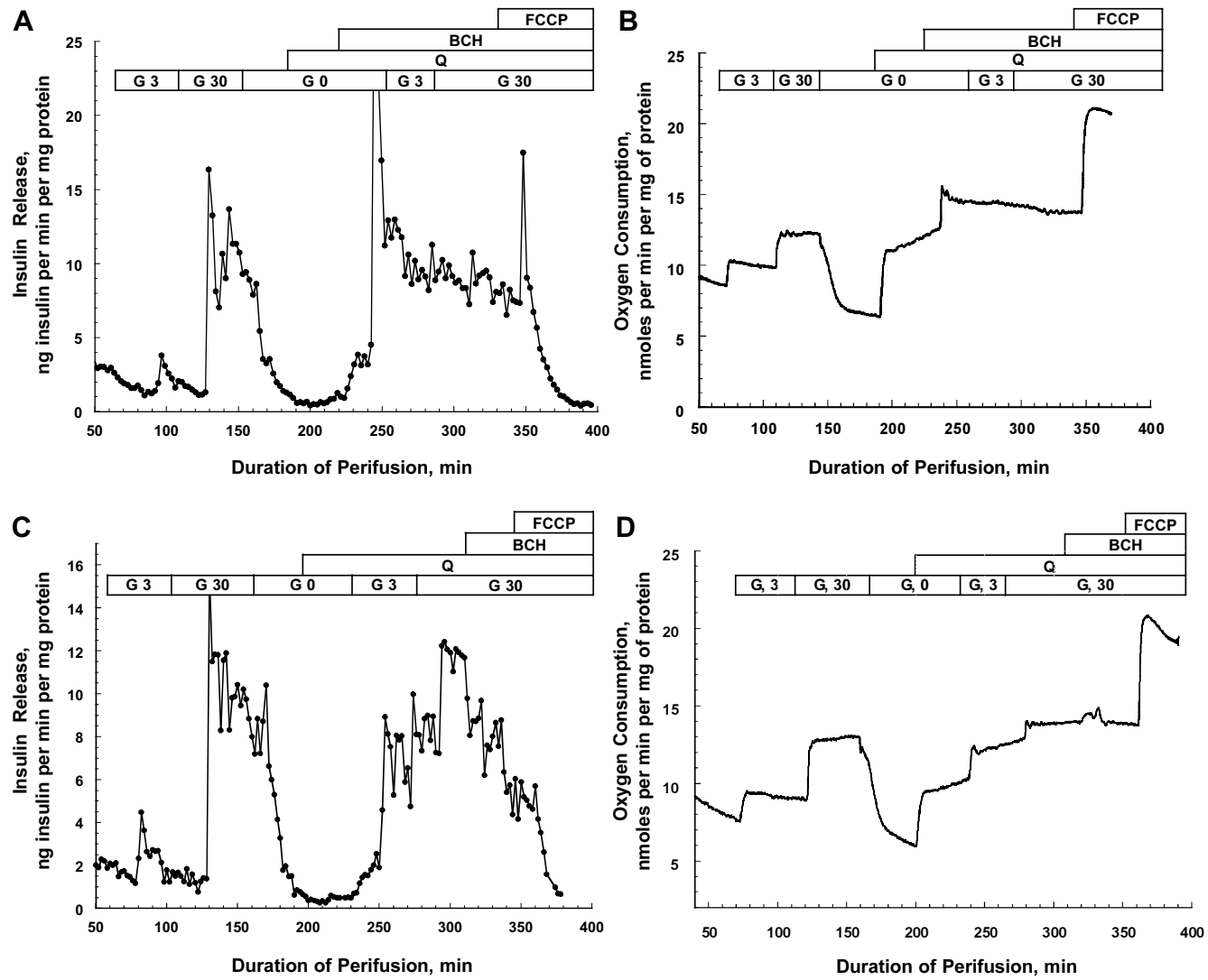

Fig. 2. Effect of glutamine on insulin release and oxygen consumption of perifused $\beta$-HC9 cells. Panel A and B: The glutamine effect was potentiated by $\mathrm{BCH}$. Panel $\mathrm{C}$ and D: Synergistic effect of glutamine and glucose on insulin release and oxygen consumption.

Each curve represents the mean of several insulin release and oxygen tracings $(n=3-5)$. See Table 1 for statistical information

These data suggest that glutamine is the major contributing stimulus in an AAM but that its action requires the presence of $\mathrm{Pi}$ to stimulate glutaminase [38] and $\mathrm{BCH}$ to activate GDH [49] when it is used in the absence of the physiological AAM. This implies that the involvement of augmented AA catabolism and energy production in stimulation of hormone release is essential.

Amino Acid-induced Increase of Phosphorylation Potential In $\beta$-HC9 Cells. In order to test if the effect of $A A M+Q$ on insulin release is indeed due to an increase 
of energy production and inhibition of $\mathrm{K}_{\mathrm{ATP}}$ channels, we used two different approaches. In the first, diazoxide, a $\mathrm{K}_{\mathrm{ATP}}$ channel opener, was added during (Fig. 3A) or before (Fig. 3B) stimulation of insulin secretion by the AAM. In both cases diazoxide blocked AAM-stimulated insulin release demonstrating that the $\mathrm{K}_{\text {ATP }}$ is essential for coupling. A remarkable observation of these experiments is the lack of effect of diazoxide on the OCR which implies that cytosolic $\mathrm{Ca}^{++}$levels and the work load imposed on the system by the process of exocytosis have little influence on respiration. To further explore the relationship between insulin release and energy metabolism a second approach, non-invasive NMR technology, was used in studies of phosphorus metabolism. Figure 4A presents a typical ${ }^{31} \mathrm{P}-\mathrm{NMR}$ spectrum of superfused $\beta-\mathrm{HC} 9$ cells with low glucose $(3 \mathrm{mM})$. The spectrum clearly displays the resonances of $\mathrm{Pi}$, $\mathrm{PCr}$ and ATP $(\gamma, \alpha$ and $\beta$ ) peaks. Frequent monitoring of phosphorus-metabolites (every $5 \mathrm{~min}$ ) (Figures $4 \mathrm{~B}$ and $4 \mathrm{C}$ ) demonstrated that increasing the glucose concentration from 3 to $30 \mathrm{mM}$ elevates the phosphorylation potential markedly as evidenced by increased $\mathrm{PCr}$ and decreased Pi peak areas. However, it is striking that the changes are relatively slow compared to the brisk, 15 to 20 fold hormone and c-AMP secretory responses (compare with Figures 1 and 2 ). It is also remarkable that the ATP level changed only little due to high glucose $(30 \mathrm{mM})$. After removal of secretagogues, the PCr decreased and $\mathrm{Pi}$ increased markedly but the ATP levels were much less affected. Addition of $A A M+Q$ to $\beta-H C 9$ cells increased the phosphorylation potential (P-potential) as evidenced by rising $\mathrm{PCr}$ and declining $\mathrm{Pi}$ without significant changes in $\beta$-ATP peak areas of ${ }^{31} \mathrm{P}$ NMR spectra of superfused $\beta-\mathrm{HC} 9$

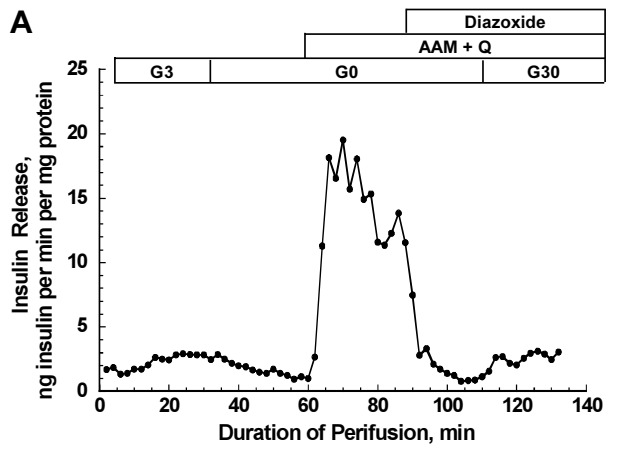

C

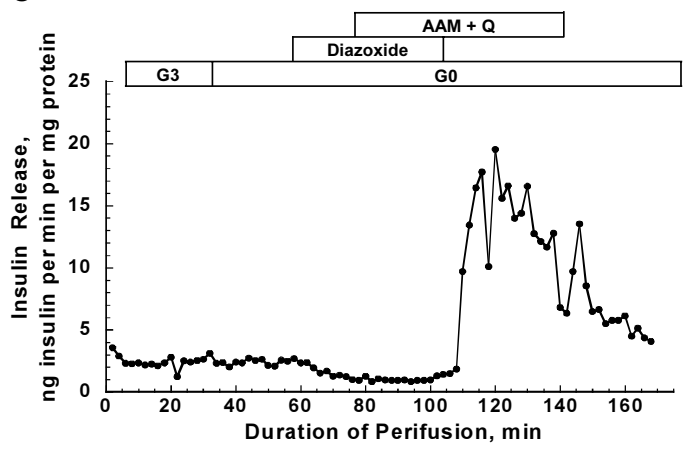

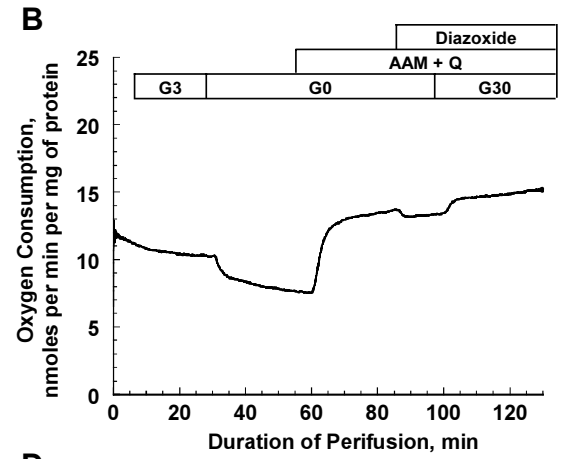

D

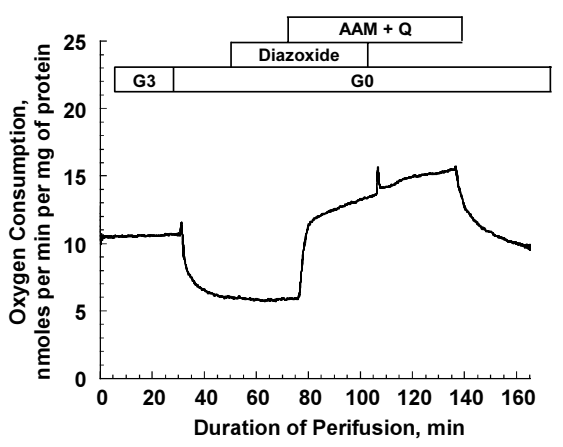

Fig. 3. Effect of diazoxide on amino acid stimulated insulin release in $\beta$-HC9 cells. Panel A: Diazoxide was added during stimulation of hormone secretion by amino acids. Panel B: Diazoxide was added before stimulation of insulin release by amino acids. Each curve represents a typical experiment $(n=3)$ 


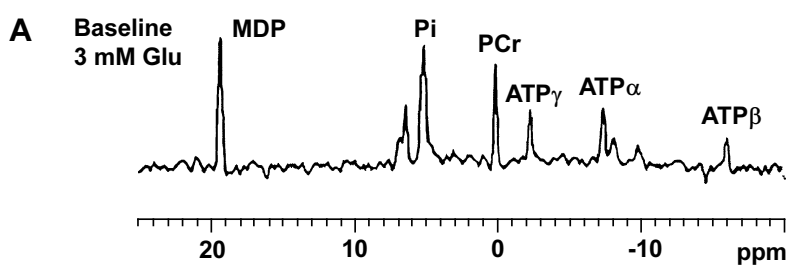

B
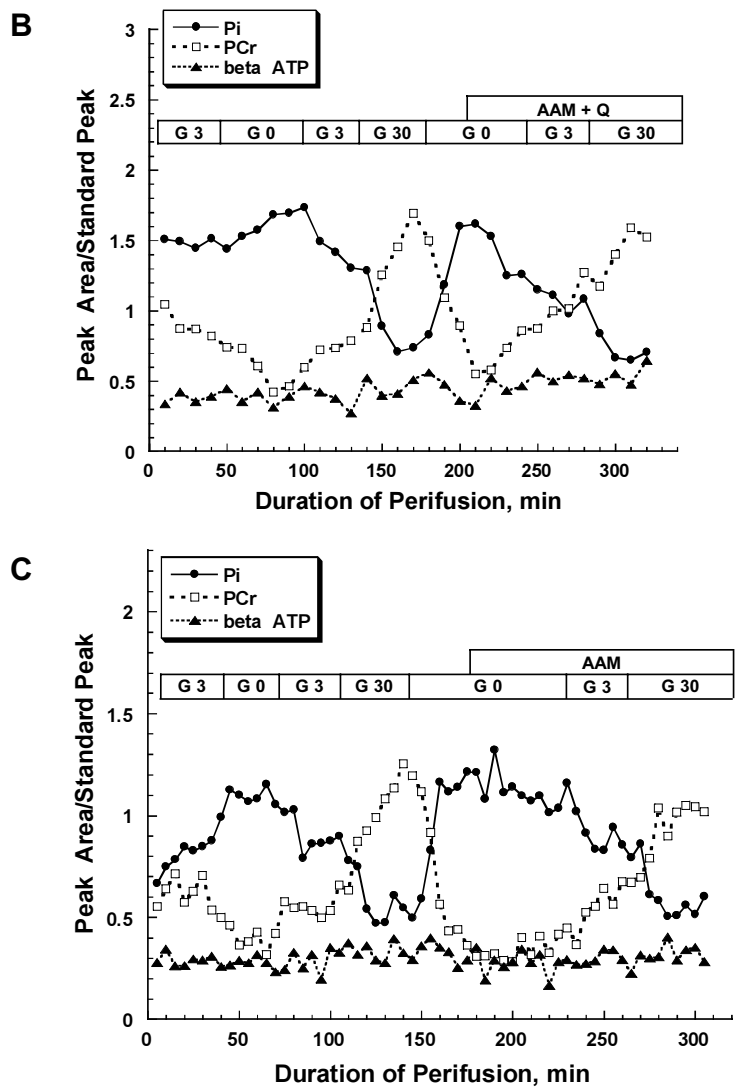

Fig. 4. Effect of glucose and amino acids on $P_{i}, P C r$ and $\beta$-ATP of perifused $\beta$-HC9 cells.

Panel A: ${ }^{31} \mathrm{P}$ NMR spectra of perifused $\beta$-HC9 cells at baseline glucose $(3 \mathrm{mM})$. Peak assignments are indicated as follows: MDP, methylene diphosphonate standard; $\mathrm{Pi}$, inorganic phosphate; $\mathrm{PCr}$, phosphocreatine; ATP, adenosine triphosphate $(\gamma, \alpha$, and $\beta)$. Panel B: Continuous monitoring (every $5 \mathrm{~min}$ ) of phosphorus metabolites during stimulation of insulin release by glucose and amino acids. Panel C: experiments were done in the same order as in panel B except that glutamine was removed from the amino acid mixture.

${ }^{31} \mathrm{P}$ NMR spectra were acquired consecutively in 5 min periods. For clarity, typical experiments are presented $(n=5)$. See Table 1 for statistical information

cells. Low $(3 \mathrm{mM})$ and high $(30 \mathrm{mM})$ glucose in the presence of $A A M+Q$ further augmented the P-potential of $\beta$-HC9 cells by increasing PCr and $\beta$-ATP $(p=0.048)$ and decreasing $\mathrm{Pi}$. Panel $\mathrm{C}$ of Figure 4 demonstrates the importance of glutamine for the P-potential as influenced by the AAM. AA without glutamine were unable to influence the P-potential of $\beta$-HC9 cells in a major way. However, 3 and $30 \mathrm{mM}$ glucose in the presence of AAM were more effective and raised the P-potential.

Cytosolic $\mathrm{pH}$ and MgADP Levels During Glucose and Amino Acid Stimulated Insulin Release. It was suggested from previous work [42] that ADP rather than ATP 
could serve as the crucial metabolic coupling factor. However, the pertinent calculations of free ADP were based on the untenable assumption that cytosolic $\mathrm{pH}$ remained constant during fuel stimulation [18, 42]. With NMR technology, cytosolic $\mathrm{pH}$ can be monitored continuously by the chemical shift between $\mathrm{Pi}$ and $\mathrm{PCr}$ of the ${ }^{31} \mathrm{P}$ spectrum. Figure $5 \mathrm{~A}$ shows the marked changes in $\mathrm{pH}$ that result from the exposure to glucose and the AAM, both in the presence and absence of glutamine. Perifusion of $\beta$-HC9 cells without glucose lowered the $\mathrm{pH}$ as the endogenous fuel stores were depleted. Low (3 $\mathrm{mM}$ ) glucose arrested the decline and elevated $\mathrm{pH}$ slightly. High $(30 \mathrm{mM})$ glucose led to a marked and rapid rise of $\mathrm{pH}$ by 0.22 units. A large fall of 0.32 units occurred when glucose was omitted from the medium. The AAM $+Q$ increased $\mathrm{pH}$ and a switch from 3 to $30 \mathrm{mM}$ glucose in the presence of the AAM + Q further increased $\mathrm{pH}$. Omitting glutamine from the medium significantly reduced the effect of amino acids on $\mathrm{pH}$ illustrating the important role of glutamine. These $\mathrm{pH}$ data were taken into account in calculations of the MgADP- levels and derivative parameters. MgADP- decreased when $3 \mathrm{mM}$ glucose was added to the medium containing the $A A M+Q$ but was not altered when glucose was raised further to $30 \mathrm{mM}$. The corresponding temporal profiles of the ATP/MgADP ratio and the P-potential provide a more comprehensive picture of $\beta$-cell energy metabolism in the more than five hour course of fuel stimulation. The impact of glutamine is perhaps the most striking as apparent from panels $B$ and $C$ of Figure 5. The ATP/MgADP ratio and the energy potential correlate most closely with fuel stimulated insulin release. It must, however, be reemphasized that metabolic changes trailed behind the insulin and c-AMP release responses.

Opposing Effects of Amino Acids and Glutamine on Internal $\mathrm{Na}^{+}$levels in $\beta$-HC9 Cells. The rise of $\mathrm{pH}$ in response to glucose is probably due to activation of $\mathrm{Na}^{+} / \mathrm{H}^{+}$ exchange [51]. The latter effect should be associated with changes in intracellular $\mathrm{Na}^{+}\left(\left[\mathrm{Na}^{+}\right]_{\mathrm{i}}\right)$ levels. In order to test this hypothesis we used ${ }^{23} \mathrm{Na} \mathrm{NMR}$ to monitor the free sodium concentration in $\beta$-HC9 cells. Previously we reported that glucose induces a dose dependent decrease in $\left[\mathrm{Na}^{+}\right]_{\mathrm{i}}[10]$. Figure 6 shows the changes in intracellular sodium (panel A) and insulin release (panel B) during perifusion with amino acids and glutamine alone. When cells were perifused with glutamine alone $\left[\mathrm{Na}^{+}\right]_{i}$ levels decreased slightly as compared to baseline. $\mathrm{BCH}$ caused a marked reduction of internal $\left[\mathrm{Na}^{+}\right]_{i}$. Exposure of $\beta-\mathrm{HC} 9$ cells to the AAM without glutamine increased $\left[\mathrm{Na}^{+}\right]_{i}$. The subsequent addition of $\mathrm{BCH}$ to the glutamine free AAM increased $\left[\mathrm{Na}^{+}\right]_{\mathrm{i}}$ further. Glucose at $3 \mathrm{mM}$, when superimposed on this stimulus mixture, decreased $\left[\mathrm{Na}^{+}\right]_{i}$ slightly, yet glutamine addition to the perfusate resulted in a $40 \%$ decrease of cytosolic $\left[\mathrm{Na}^{+}\right]_{i}$. BCH markedly potentiated insulin release in the presence of glutamine, but was unable to enhance insulin release in the presence of AAM without glutamine (panel B). This refractory state was partially reversed by the addition of $3 \mathrm{mM}$ glucose. It is not clear why the combination of $A A M+Q+$ Glucose $(3 \mathrm{mM})+B C H$ was unable to elicit a maximal secretory response comparable to that seen at the beginning of the experiment.

Effect of High Glucose on Lactate, Alanine, Aspartate, Glutamine and Glutamate levels of $\beta$-HC9 Cells. The above data show that the effect of a complete physiological AAM on insulin release is probably the result of increased energy production as evidenced by increased oxygen consumption and phosphorylation potential and by the observation that these effects can be blocked by the $\mathrm{K}_{\mathrm{ATP}}$ channel activator diazoxide. This suggests that in the absence of glucose, the metabolism of amino acids and glutamine leads to the flux of metabolites into the citric acid cycle, thereby stimulating energy production and insulin release. We also tested the alternative 
A
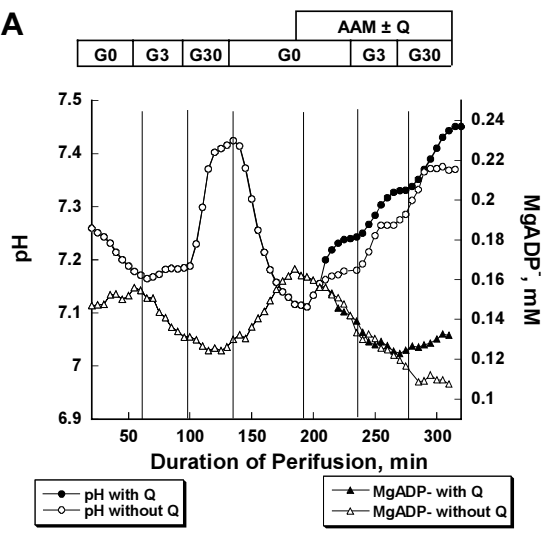

B
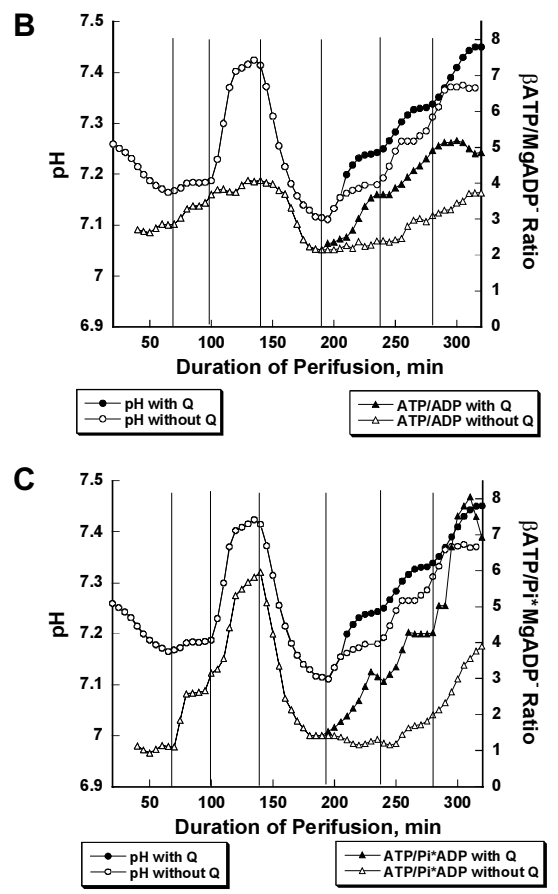

Fig. 5. Effect of glucose and amino acids on intracellular pH and MgADP-, the ATP/ADP ratio and the P-potential (ATP/ $\left.\mathbf{P}_{\mathrm{i}} \times \mathbf{A D P}\right)$ in perifused $\beta$-HC9 cells.

Changes in intracellular $\mathrm{pH}$ were used to calculate free MgADP-. Note: The data are presented as moving averages of 3 points. The results of all experiments $(n=6)$ were comparable up to the $190 \mathrm{~min}$ time point and were combined. After that, one set of experiments contained $2 \mathrm{mM}$ glutamine in the amino acid mixture (filled circles $(\mathrm{pH})$ and triangles $\left(\mathrm{MgADP}^{-}\right)$) whereas in the second set glutamine was omitted (open circles $(\mathrm{pH})$ and triangles $\left(\mathrm{MgADP}^{-}\right)$). Panel $\mathrm{A}$ : Changes in intracellular $\mathrm{pH}$ and calculated free MgADP- Panel B: Changes in the ATP/MgADP ratio; Panel C: Changes in the P-potential (ATP/P $\times A D P)$. Note that the $\mathrm{pH}$ data are shown in all panels to facilitate comparison of kinetics. Also note that the insul in release dynamics were comparable to those in Figures $1 \mathrm{~A}$ and 1B. See Table 1 for statistical information

hypothesis that glucose might redirect the flux of intermediates towards the formation of amino acids by reductive amination of $\alpha$-ketoglutarate with glutamate dehydrogenase and by transaminations and asked whether the major cataplerotic amino acid derivatives of glycolysis and the citric acid cycle, i.e. alanine, aspartate, glutamate and glutamine, could serve as messengers in glucose-induced insulin secretion as 

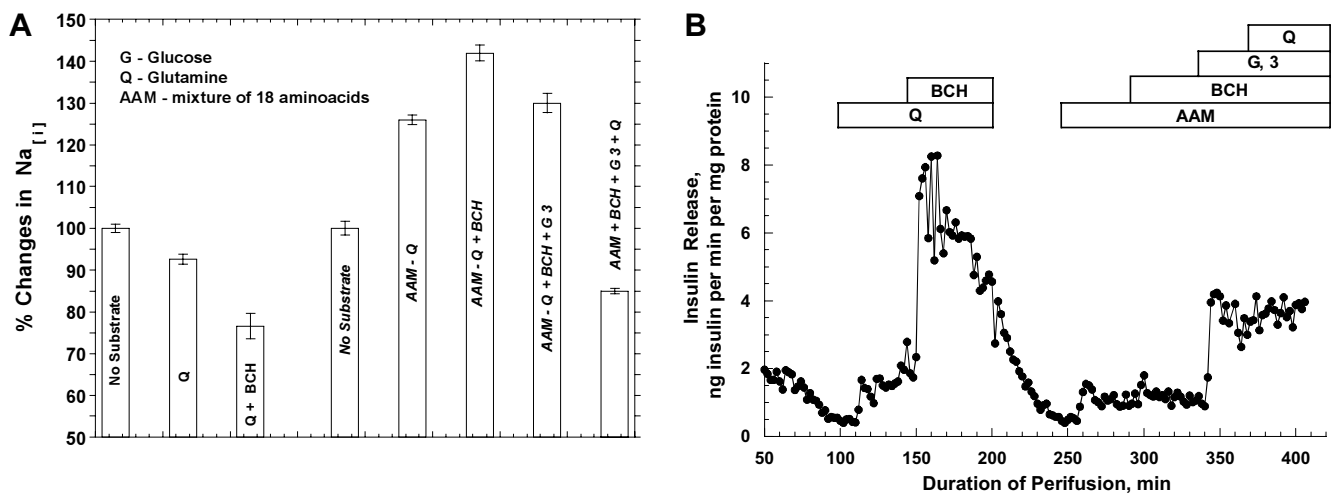

Fig. 6. Changes in intracellular $\mathrm{Na}^{+}$levels (panel A) and insulin release (panel B) during continuous long-term perifusion experiments under the influence of different physiological stimuli. Panel A: Sodium levels are presented as average values for all steady state measurements (each intervention lasted $30 \mathrm{~min}$ ). Panel $B$ : Insulin release from the same experiments $(n=4)$. Where not indicated the concentrations were as follows: AAM, $3.5 \mathrm{mM} ; \mathrm{Q}, 2 \mathrm{mM} ; \mathrm{BCH}, 10 \mathrm{mM}$.

See Table 1 for statistical information

proposed for the latter two molecules by Maechler and Wollheim [36] and Li et al. [31], respectively.

Proton- and phosphorus-NMR analysis was applied to measure intracellular metabolites including lactate, alanine, aspartate, glutamate, glutamine, $\mathrm{PCr}$ and ATP in extracts prepared from perifused $\beta-\mathrm{HC} 9$ cells. The concentration of glutamine in the medium was reduced to $0.5 \mathrm{mM}$ in order to magnify the effect of high glucose and to diminish analytical difficulties due to contamination of the cell extracts by extracellular glutamine. The focus is here on the portion of the experiment which deals with glucose effect. High glucose doubled amino acid induced insulin release transiently (Fig. 7A) and increased oxygen consumption slightly but persistently (Fig. 7B). These effects were associated with increased cellular concentrations of lactate, alanine, glutamate and glutamine but markedly decreased aspartate levels (Table 2 and Fig. 8, note that the lactate and alanine data are not shown because the focus is on the citric

Table 2. ${ }^{1} \mathrm{H}$ and ${ }^{31} \mathrm{P}$ NMR Analysis of Glutamine, Glutamate, Aspartate, $\mathrm{PCr}$ and ATP Levels in $\beta$-HC9 Cell Extracts

\begin{tabular}{|c|c|c|c|c|c|c|c|}
\hline Protocols & Parameters & Glutamine & Glutamate & Aspartate & $\begin{array}{l}\text { Insulin } \\
\text { Release }\end{array}$ & $\mathrm{PCr}$ & ATP \\
\hline \multirow{2}{*}{$\begin{array}{l}\text { Protocol A } \\
(n=6)\end{array}$} & $\begin{array}{l}\text { AAM }(3.5 \mathrm{mM}) \\
+ \text { Glutamine }(0.5 \mathrm{mM})\end{array}$ & $11.7 \pm 1.19$ & $35.5 \pm 2.78$ & $66.7 \pm 7.46$ & $100 \%$ & $40.4 \pm 3.99$ & $9.9 \pm 1.24$ \\
\hline & $\begin{array}{l}\text { AAM }(3.5 \mathrm{mM}) \\
+ \text { Glutamine }(0.5 \mathrm{mM}) \\
+ \text { Glucose }(30 \mathrm{mM})\end{array}$ & $20.7 \pm 4.07^{\star}$ & $54.6 \pm 1.74^{\star}$ & $27.4 \pm 2.75^{\star}$ & $184 \pm 8.29 \% *$ & $66.8 \pm 1.94^{\star}$ & $14.3 \pm 1.89^{\star}$ \\
\hline \multirow{2}{*}{$\begin{array}{l}\text { Protocol B } \\
\quad(n=4)\end{array}$} & $\begin{array}{l}\text { MSO }(1 \mathrm{mM}) \\
+ \text { AAM }(3.5 \mathrm{mM}) \\
+ \text { Glutamine }(0.5 \mathrm{mM})\end{array}$ & $14.3 \pm 1.23$ & $43.1 \pm 7.08$ & $41.3 \pm 2.17$ & $100 \%$ & $66.6 \pm 2.84$ & $13.8 \pm 0.82$ \\
\hline & $\begin{array}{l}\text { MSO (1 mM) } \\
+ \text { AAM }(3.5 \mathrm{mM}) \\
+ \text { Glutamine }(0.5 \mathrm{mM}) \\
+ \text { Glucose }(30 \mathrm{mM})\end{array}$ & $17.4 \pm 1.40$ & $68.2 \pm 7.34^{\star}$ & $43.6 \pm 1.88$ & $110 \pm 5.77 \%$ & $91.5 \pm 8.99^{*}$ & $13.1 \pm 0.37$ \\
\hline
\end{tabular}

At the end of experiment, the beads containing cells were filtered to remove the perifusion medium, washed with cold KHB buffer, frozen in liquid nitrogen, and extracted with perchloric acid. Values are mean \pm SE of 4-5 experiments. Concentrations of metabolites are given in $\mathrm{nmol} / \mathrm{mg}$ protein.

${ }^{\star}(p \leq 0.05)$ compared within the same protocol. 

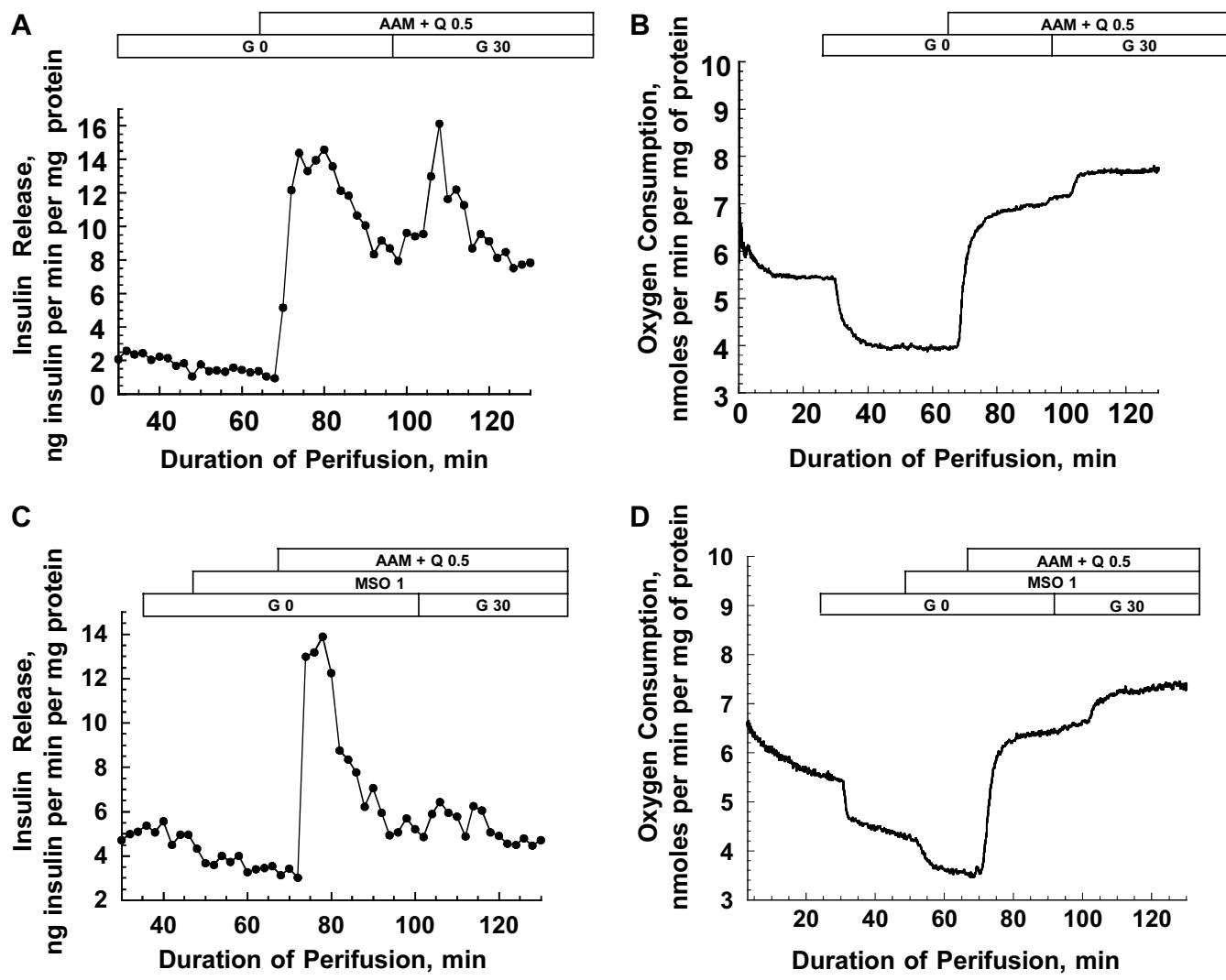

Fig. 7. Effect of MSO on glucose stimulated insulin release and oxygen consumption of perfused $\beta$-HC9 cells.

Panel A and B: Control experiment. Panel C and D: Methionine-Sulfoximine (MSO, $1 \mathrm{mM}$ ) was added to inhibit glutamine synthetase. See Table 2 for statistical information

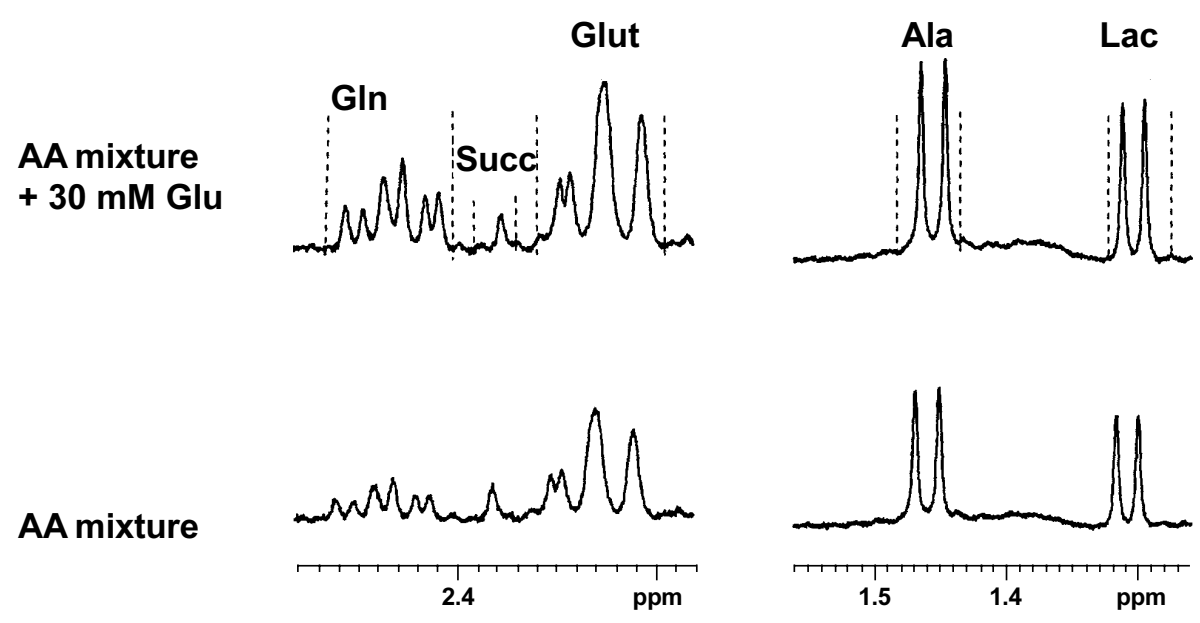

Fig. 8. Effect of high glucose on intracellular metabolites levels in $\beta$-HC9 cell extracts measured by ${ }^{1} \mathbf{H}$ NMR. Sections of the ${ }^{1} \mathrm{H}$ NMR spectrum is shown. Peak assignments are as follows: Ala, alanine; Gln, glutamine; Lac, lactic acid; Succ, succinic acid; Glut, glutamic acid 
acid cycle derivatives). At the same time the total concentration of $\mathrm{PCr}$ and ATP increased by $65 \%$ and $44 \%$, respectively. Methionine sulfoximine (MSO), an inhibitor of glutamine synthetase, decreased the delayed phase of insulin secretion due to the $A A M+Q$ and blocked glucose-induced insulin release (Fig. 7C) but did not prevent the increase in oxygen consumption nor did it impair the energy potential as indicated by normal and higher levels of ATP and PCr, respectively (Fig. 7D and Table 2). The baseline level of aspartate was somewhat reduced after addition of MSO but lacked the characteristic drop following high glucose. Glutamate was high, both in the presence and absence of glucose. Glutamine levels were unchanged by MSO but did increase barely under the influence of glucose consistent with the inhibition of glutamine synthase by MSO.

\section{DISCUSSION}

\section{Methodological Considerations}

At the outset advantages and limitations of the present model system using perifused agarose embedded $\beta-\mathrm{HC} 9$ cells need to be discussed. There are distinct benefits in using this model system for studying fuel stimulated insulin secretion: 1) The availability of large batches of insulin secreting cells allows the application of powerful techniques as for instance $\mathrm{P}$-, $\mathrm{Na}$ and proton-NMR which are too insensitive for experimenting with isolated pancreatic islets; 2) The approach avoids the complication arising from the admixture of non $\beta$-cells in the preparation which compromises many studies with isolated islets of Langerhans; 3 ) The glucose dose response curve with a threshold of 3-4 $\mathrm{mM}$ is in the physiological range consistent with involvement of glucokinase as glucose sensor and normal operation of the $\mathrm{K}_{\mathrm{ATP}}$ and $\mathrm{Ca}^{2+}$ channels. There are, however, certain features and drawbacks which have to be kept in mind when interpreting results obtained with this $\beta$-cell model system: 1) The phosphodiesterase inhibitor IBMX is required to permit optimal studies of fuel stimulated insulin release; 2) Cells are cultured and perifused in the presence of $25 \mathrm{mM}$ creatine, a measure taken to facilitate studying the P-potential by NMR but creating perhaps an artificially high intracellular P-creatine pool as energy trap; 3 ) The $\beta$-HC9 cells are highly responsive to an amino acid mixture independent of glucose, in striking contrast to normal $\beta$-cells; and 4) The temporal resolution of phosphorous-NMR is relatively low compared to the rapidity of onset of fuel stimulated respiration and insulin release. On balance, advantages far outweigh the drawbacks as illustrated by previous studies and to become apparent in the discussion of the present results.

\section{Summary and General Discussion of Study}

The present results, carefully considered as a whole, are best explained by the classical hypothesis that an increased P-potential is the critical driving force for insulin release stimulated by glucose and by amino acids but they also illustrate the great difficulties inherent in mechanistic studies of stimulus secretion coupling of this process. Using large batches of the pancreatic cell line $\beta$-HC9 in a continuous perifusion system we studied 7 primary parameters (the OCR, cytosolic $\mathrm{pH}$, free ATP, inorganic $P, P$-Creatine, $C-A M P$ release and insulin secretion) and 3 derivative parameters (free ADP, the ATP/ADP ratio and the P-Potential $A T P / P_{i} \times A D P$ ) as influenced by glucose and amino acid stimulation and we also determined the cellular levels of aspartate, glutamate and glutamine at single time points following a glucose load superimposed on a physiological AAM. Among these parameters are metabolic 
coupling factors (MCF), second messengers (SM) and metabolic indicators (MI). Furthermore, diazoxide, the specific activator of the $\mathrm{K}_{\mathrm{ATP}}$ channel, $\mathrm{MSO}$, an inhibitor of glutamine synthase, and omission of inorganic $P$ in the perifusate were employed to facilitate the exploration of coupling mechanisms. The results of this study are summarized as follows: Insulin secretion, c-AMP release and the OCR respond rapidly and markedly to fuel stimulation suggesting that they are causally related. However, the association is not absolute: 1) Diazoxide blocked insulin release but had little or no effect on the OCR; 2) Phosphate omission greatly reduced AA induced insulin release but did not affect the OCR and the C-AMP release; and 3) The level changes of MCFs and changes of derivative Mls are much slower than the rates of change observed in insulin and c-AMP release and the OCR. This dissociation can not be interpreted to indicate that increased oxidative phosphorylation and the participation of the PKA system are not essential for fuel stimulated insulin release. The results merely show that it is possible to uncouple metabolism or SM production from insulin secretion by well established (in the case of diazoxide) or less well understood mechanisms (the omission of phosphate in AA stimulation). Levels of aspartate, glutamate and glutamine change dramatically when $\beta-\mathrm{HC} 9$ cells are stimulated with glucose on a background of a physiological AAM. However, neither one of them qualifies as MCF according to our definition. In the paragraphs below specific aspects of these results and conclusions are discussed in detail.

\section{Discussion of Specific Aspects of the Present Study}

The role of ATP and free ADP in stimulus-secretion coupling in $\beta$-HC9 cells. The metabolism of amino acids and flux through GDH is dependent on the energy status of the cell [16, 32]. In the fuel-deprived state, glutaminase and GDH are activated and glutamine synthesis is slow such that there is a net flux in the catabolic direction. The results of the present study suggest that in glucose free media, physiological amino acid mixtures including glutamine stimulate insulin release of $\beta-\mathrm{HC} 9$ cells and this effect is associated with enhanced flux through GDH in direction of the citric acid cycle as evidenced by an increase in oxygen consumption and the phosphorylation potential $\left(A T P / P_{i} \times A D P\right)$. This amino acid induced rise in the phosphorylation potential should lead to closure of the ATP-sensitive $\mathrm{K}^{+}$channels and trigger insulin release as is seen when glucose is the stimulus. Indeed, hyperpolarization of the $\beta$-cell membrane by diazoxide completely abolished the amino acid and glucose induced insulin release proving the involvement of $\mathrm{K}_{\text {ATP }}$ channels. However, it is still a matter of debate whether it is the change in the concentration of ATP, of MgADP or both which influence $\mathrm{K}_{\text {ATP }}$ channel activity. A substantial fraction of the ATP $(68 \%)$ and ADP (45\%) within the $\beta$-cell is nondiffusible and contained in intracellular organelles (especially the insulin secretory granules) [8]. Measurements of [ATP] $]_{i}$ in purified rat $\beta$-cells suggest that $[A T P]_{i}$ is $\sim 2 \mathrm{mmol} / \mathrm{l}\left(2 \mathrm{pmol} / 10^{3}\right.$ cells) in the absence of glucose and increases to more than $4 \mathrm{mmol} / \mathrm{l}$ cells ( $\geq 4 \mathrm{pmol} / 10^{3}$ cells) when glucose is raised to $10 \mathrm{mmol} / \mathrm{l}[7]$. However, a change in $[A T P]_{i}$ on exposure to glucose is not universally observed [18]. The present results demonstrate that free ATP of B-cells is not detectably altered by glucose. The B-ATP peak significantly increased (by $30 \%$; $p=0.048$ ) only when glucose was combined with amino acids. In support of these data, the authors of a recent paper reported only modestly increased ATP resulting from glucose metabolism and a relatively high [ATP]/[ADP] value even in low glucose [15]. Therefore, one might question a role of ATP as critical physiological regulator of $\mathrm{K}_{\text {ATP }}$ channel activity [44]. On the other hand, intracellular free $\mathrm{MgADP}^{-}$stimulates $\mathrm{K}_{\mathrm{ATP}}$ channel activity, and it has been suggested that ADP, and therefore the ATP/ADP ratio, is 
responsible for channel regulation in vivo [2, 5, 29, 44]. MgADP- shifts the ATP concentration-inhibition curve to a higher intracellular ATP concentration [27]. There have been few estimates of free MgADP in $\beta$-cells which show that increasing concentrations of glucose are associated with a decline in the concentration of free $\mathrm{ADP}$ in the range that can inhibit $\mathrm{K}_{\text {ATP }}$ channel activity $[18,42]$. However, all previous calculations of MgADP- used the assumption that $\mathrm{pH}$ remained constant during fuel stimulated insulin release $[18,42]$. If we assume that $\mathrm{pH}$ is constant then MgADPwould decrease by about $50 \%$ when the perifusion is switched from low to high glucose in the present study. However, according to our data and calculations, marked alkalization of $\beta$-cells due to high glucose results in unchanged MgADP- when glucose was raised from 3 to $30 \mathrm{mM}$.

Results of the present study showed that amino acids and glucose also causes a marked increase in phosphocreatine and a fall in phosphate. These data are in good agreement with previous published results [28] showing that the phosphocreatine concentration in isolated mouse islets clearly increased in response to a rise of the glucose concentration from $0.5 \mathrm{mM}$ to $15 \mathrm{mM}$. Phosphocreatine reduces the ability of ADP to stimulate $\mathrm{K}_{\text {ATP }}$ channel activity in $\beta$-cells [28].

Tarasov et al. [54] suggested recently that, similarly to cardiac muscle [12], $\beta$-cell have an intracellular phoshotransfer network with creatine kinase linking ATP generation to $\mathrm{K}_{\text {ATP }}$ channel closure and adenylate kinase regulating $\mathrm{K}_{\text {ATP }}$ channel opening. Such a system might shuttle high energy-rich phosphates from the mitochondria to the plasma membrane without much change in ATP. In the microenvironment of the channel adenylate kinase could convert AMP and ATP to ADP, promoting channel opening, whereas creatine kinase could catalyze the transfer of phosphate from phosphocreatine to ADP, producing creatine and ATP and, consequently, channel closure. This process could take place as early response to fuel exposure but may manifest itself with a delay by the increased P-potential.

There are at least two other agents known to modulate the ATP sensitivity of the $\mathrm{K}_{\text {ATP }}$ channel: $\mathrm{PIP}_{2}$ (phosphatidylinositol-4,5-bisphosphate) and related phosphoinositides (PPIs) [3, 14], and also long-chain acyl-CoA esters (LC-CoAs) [19, 30, 46]. They both decrease the ability of ATP to close the $\mathrm{K}_{\text {ATP }}$ channel.

Activation of the $c$-AMP system by fuel stimulation of $\beta$-HC9 cells. The rate of c-AMP release is markedly increased coincidentally with insulin secretion following glucose or AA stimulation of $\beta$-HC9 cells. Even though few replicates of the results are available the data are internally consistent and derive great strength from their context and extended time course of their profiles. The increased production of the SM C-AMP is most likely the result of enhanced fuel metabolism as apparent from the data set presented in Figure 1. The most plausible explanation is that an elevated intracellular calcium level is the cause of adenylate cyclase activation $[41,55]$. It should be obvious that any discussion of metabolic coupling mechanisms involved in fuel stimulated insulin release including "triggering” and „amplification” must consider the participation of the PKA signaling pathway as essential.

The role of glutamine and $\mathrm{Pi}$ in insulin secretion. The results also suggest a prominent role of glutamine in amino acid stimulated insulin release in $\beta$-HC9 cells because omitting glutamine from the amino acid mixture markedly reduces insulin release, oxygen consumption, and abolishes changes in the phosphorylation potential. However, glutamine alone is not sufficient to stimulate insulin release by $\beta-\mathrm{HC} 9$ cells. Stimulation of $\mathrm{GDH}$ by $\mathrm{BCH}$ or adding glucose enables the effect of glutamine on hormone release similarly to effects of $\mathrm{L}$-leucine and $\mathrm{BCH}$ on pancreatic islets $[48,49]$. 
The data also suggest a critical role for $\mathrm{Pi}$ in amino acid stimulated insulin release. Inorganic phosphate regulates the activity of glutaminase and thus adding of $\mathrm{Pi}$ leads to an increase of the glutamate concentration and enhances insulin secretion evoked by the addition of leucine [38]. It is remarkable that omitting Pi from the perfusate affects only insulin secretion but not oxygen consumption and c-AMP release suggesting that secretion and oxidation are not tightly coupled.

These studies with glutamine and inorganic phosphate clearly implicate enhanced metabolism as essential for the stimulation of insulin secretion.

The role of intracellular $\mathrm{H}^{+}$and $\mathrm{Na}^{+}$in hormone release. The changes in intracellular $\mathrm{H}^{+}$and $\mathrm{Na}^{+}$ions are tightly coupled in pancreatic $\beta$-cells. High glucose induces an increase in $\mathrm{pH}_{\mathrm{i}}$ and this effect is dependent on the presence of extracellular $\mathrm{Na}^{+}$ and is inhibited by $5-\left(\mathrm{N}\right.$-ethyl- $\mathrm{N}$-isopropyl) amiloride, a blocker of $\mathrm{Na}^{+} / \mathrm{H}^{+}$exchange [26]. However, in the presence of a $\mathrm{Na}^{+} / \mathrm{H}^{+}$exchange inhibitor, stimulation of $\beta$-cell with glucose leads to acidification, unmasking the acid load imposed by metabolism of the sugar [26]. Shephherd and Henquin [51] proposed that activation of the $\mathrm{Na}^{+} / \mathrm{H}^{+}$ exchanger leads to overcorrection of the acidification action of glucose metabolism. Activation of the $\mathrm{Na}^{+} / \mathrm{H}^{+}$exchanger should lead to elevation of the intracellular $\mathrm{Na}^{+}$ level. However, we [10] and others [56] have shown that glucose induces a dose dependent decrease in intracellular $\mathrm{Na}^{+}$. It is more likely that intracellular $\mathrm{pH}$ increased because of $\mathrm{H}^{+}$uptake by secretory granules during islet stimulation with glucose [52] consistent with the observation that cytosolic and granular $\mathrm{pH}$ change in opposite directions upon glucose stimulation. Amino acids also cause an alkalinization of $\beta$ cells, and this effect depends on the presence of glutamine in the amino acid mixture. One should not ignore $\left[\mathrm{H}^{+}\right]_{i}$ as a potential physiological regulator in stimulus-secretion coupling of $\beta$-cells particularly because changes in $\mathrm{pH}$ may modulate ATP-regulated $\mathrm{K}^{+}$channel activity [26, 39, 43]. Furthermore, $\mathrm{pH}$ affects glutaminase activity [38]. The marked decrease in the rate of glutamine breakdown at a $\mathrm{pH}$ lower than 7.4 indicates that when intracellular $\left[\mathrm{H}^{+}\right]_{i}$ increases, glutamine catabolism decreases [38].

Glutamine alone or with $\mathrm{BCH}$ also lowers the $\mathrm{Na}^{+}$level whereas an amino acid mixture with or without glutamine increases $\beta$-cell intracellular ion levels. Because glutamine metabolism influences the P-potential, it is logical to propose that this elevation of energy production may activate the $\mathrm{Na}^{+} / \mathrm{K}^{+}$pump and cause an extrusion of $\mathrm{Na}^{+}$from the $\beta$-cells.

Do intracellular aspartate, glutamate or glutamine serve as a metabolic coupling factor in fuel-stimulated insulin secretion? Glutaminolysis may be blocked in the fuel energized $\beta$-cell [32]. Glutaminase and GDH are inhibited while glutamine synthesis may be activated resulting in net flux in the direction of glutamate and glutamine. Addition of glucose to $\beta$-HC9 cells oxidizing amino acids should therefore energize the cells and lead to inhibition of GDH and a redirection of the flux into anabolic pathways (e.g. a rise of glutamate and glutamine). Maechler and Wollheim [36] suggested that glutamate, released from the mitochondria, may act as an intracellular messenger that couples glucose metabolism to insulin secretion. Their hypothesis was based on the following observations and considerations: 1) High glucose generated glutamate from $\beta$-cell mitochondria resulting in an increase of cellular glutamate concentration of about 5 fold in rat insulinoma INS-1 cells or in isolated human pancreatic islets [25]; 2) The mitochondrial poison FCCP inhibited the production of glutamate during glucose stimulation of INS-1 cells [36]; 3) In permeabilized cells, under conditions of fixed $\left[\mathrm{Ca}^{2+}\right]_{i}$, glutamate directly stimulated insulin exocytosis $[17,45]$; 4) Dimethyl-glutamate had no effect on the mitochondrial membrane potential 
in INS-1 cells, suggesting that glutamate participates directly in the secretory process downstream of mitochondrial activation [36]. It was also suggested that glutamate can be taken up by secretory granules because inhibitors of vesicular glutamate transport suppressed the glutamate-evoked exocytosis. However, the "glutamate hypothesis" was challenged by reports suggesting that glucose was unable to affect glutamate levels in islets from ob/ob mice [6, 21], rats [35] and insulinoma cells [34]. Furthemore, the ability of glutamate dimethyl ester to increase insulin secretion was attributed to its use as a nutrient by $\beta$-cells [47]. Altering the islet glutamate content by adding glutamine [35, 37, 38] did not induce insulin release unless GDH was activated by leucine or its non-metabolized analogue $\mathrm{BCH}[40,49]$. Because of glutamate's putative role in the amplification pathway, the glutamate hypothesis was tested in conditions of clamping of $\left[\mathrm{Ca}^{2+}\right]$ at an elevated level by depolarizing $\beta$-cells either with a sulfonylurea compounds or by high $\mathrm{KCl}$ in the presence of diazoxide [4]. The amplification of secretion produced by glucose was accompanied by an increase in islet glutamate. However, glutamine $(0.5-2 \mathrm{mM})$ augmented islet glutamate without affecting insulin secretion, whereas glucose augmented secretion without influencing glutamate levels. Activation of $\mathrm{GDH}$ by $\mathrm{BCH}$ lowered islet glutamate but increased insulin secretion [4]. This dissociation between changes in islet glutamate and insulin secretion was used as argument against a role of $\beta$-cell glutamate in the amplification of insulin secretion by glucose [4].

In a recent paper [31] it was suggested that glutamine may serve as cofactors of insulin release. The hypothesis was based on observation that glutamine elicited a secretory response under conditions of elevated $\left[\mathrm{Ca}^{2+}\right]_{\mathrm{i}}$ in SUR1 knockout islets and because DON, a glutamine analogue, reversed MSO inhibition of glucose stimulated insulin release.

Because of the contradictory literature, we have revisited this topic. According to our ${ }^{1} \mathrm{H}$ NMR analysis, the level of glutamine and glutamate were elevated and aspartate levels decreased following glucose stimulated insulin release which would be consistent with the idea that glutamate, glutamine or both serve a positive metabolic coupling factors and might even suggest that aspartate is a negative coupling factor comparable to MgADP. Furthermore, MSO, while not depressing the P-potential, abolished hormone release even though glutamate rose whereas glutamine and aspartate were unchanged. It may require the concerted change of all three amino acids to exert a positive effect on insulin secretion. However, since intracellular receptor-like molecular targets for these amino acids are not known in pancreatic $\beta$ cells we consider them as metabolic indicators (Mls) merely showing that disruption of critical glucose induced changes of amino acid metabolism by the glutamine synthase inhibitor MSO blocks insulin secretion by mechanisms yet to be elucidated. It seems to be premature to assign MCF status to any one of these amino acids.

1. Albano J.D., Barnes G.D., Maudsley D.V. e. a. Factors affecting the saturation assay of cyclic AMP in biological systems. Anal. Biochem, 1974; 60: 130-141.

2. Ashcroft S.J. The beta-cell K(ATP) channel. J. Membr. Biol, 2000; 176: 187-206.

3. Baukrowitz T., Schulte U., Oliver D. e. a. PIP2 and PIP as determinants for ATP inhibition of KATP channels. Science, 1998; 282: 1141-1144.

4. Bertrand G., Ishiyama N., Nenquin M. e. a. The elevation of glutamate content and the amplification of insulin secretion in glucose-stimulated pancreatic islets are not causally related. J. Biol. Chem, 2002; 277: 32883-32891. 
5. Corkey B.E., Deeney J.T., Glennon M.C. e. a. Regulation of steady-state free $\mathrm{Ca}^{2+}$ levels by the ATP/ADP ratio and orthophosphate in permeabilized RINm5F insulinoma cells. J. Biol. Chem, 1988; 263: 4247-4253.

6. Danielsson A., Hellman B., Idahl L.A. Levels of 6 -ketoglutarate and glutamate in stimulated pancreatic-cells. Horm. Metab. Res, 1970; 2: 28-31.

7. Detimary P., Dejonghe S., Ling Z. e. a. The changes in adenine nucleotides measured in glucose-stimulated rodent islets occur in beta cells but not in alpha cells and are also observed in human islets. J. Biol. Chem, 1998; 273: 3390533908.

8. Detimary P., Jonas J.C. Henquin J.C. Possible links between glucose-induced changes in the energy state of pancreatic $\beta$-cells and insulin release. Unmasking by decreasing a stable pool of adenine nucleotides in mouse islets. J. Clin. Invest, 1995; 96: 1738-1745.

9. Doliba N.M., Qin W., Vatamaniuk M.Z. e. a. Cholinergic regulation of fuel-induced hormone secretion and respiration of SUR1-/- mouse islets. Am. J. Physiol. Endocrinol. Metab, 2006; 291: E525-535.

10. Doliba N.M., Vatamaniuk M.Z., Buettger C.W. e. a. Differential effects of glucose and glyburide on energetics and $\mathrm{Na}^{+}$levels of beta-HC9 cells: nuclear magnetic resonance spectroscopy and respirometry studies. Diabetes, 2003; 52: 394-402.

11. Doliba N.M., Wehrli S.L., Babsky A.M. e. a. Encapsulation and perfusion of mitochondria in agarose beads for functional studies with 31P-NMR spectroscopy. Magn. Reson. Med, 1998; 39: 679-684.

12. Dzeja P.P., Terzic A. Phosphotransfer reactions in the regulation of ATP-sensitive $\mathrm{K}^{+}$channels. Faseb. J, 1998; 12: 523-529.

13. Erecinska M., Bryla J., Michalik M. e. a. Energy metabolism in islets of Langerhans. Biochim. Biophys. Acta, 1992; 1101: 273-295.

14. Fan Z., Makielski J.C. Anionic phospholipids activate ATP-sensitive potassium channels. J. Biol. Chem, 1997; 272: 5388-5395.

15. Fridlyand L.E., Ma L., Philipson L.H. Adenine nucleotide regulation in pancreatic beta-cells: modeling of ATP/ADP-Ca ${ }^{2+}$ interactions. Am. J. Physiol. Endocrinol. Metab, 2005; 289: E839-848.

16. Gao Z.Y., Li G., Najafi H. e. a. Glucose regulation of glutaminolysis and its role in insulin secretion. Diabetes, 1999; 48: 1535-1542.

17. Gembal M., Gilon P., Henquin J.C. Evidence that glucose can control insulin release independently from its action on ATP-sensitive $\mathrm{K}^{+}$channels in mouse $\beta$-cells. J. Clin. Invest, 1992; 89: 1288-1295.

18. Ghosh A., Ronner P., Cheong E. e. a. The role of ATP and free ADP in metabolic coupling during fuel-stimulated insulin release from islet beta-cells in the isolated perfused rat pancreas. J. Biol. Chem, 1991; 266: 22887-22892.

19. Gribble F.M., Proks P., Corkey B.E., Ashcroft F.M. Mechanism of cloned ATPsensitive potassium channel activation by oleoyl-CoA. J. Biol. Chem, 1998; 273: 26383-26387.

20. Gupta R.K., Yushok W.D. Noninvasive ${ }^{31} \mathrm{P}$ NMR probes of free $\mathrm{Mg}^{2+}, \mathrm{MgATP}$, and MgADP in intact Ehrlich ascites tumor cells. Proc. Natı. Acad. Sci. USA, 1980; 77: 2487-2491.

21. Gylfe E., Hellman B. Role of glucose as a regulator and precursor of amino acids in the pancreatic beta-cells. Endocrinology, 1974; 94: 1150-1156.

22. Hellerstrom C., Andersson A., Welsh M. Respiration of the pancreatic $\beta$-cell: effects of glucose and 2-aminonorbornane-2-carboxylic acid. Horm. Metab. Res, 1980; Suppl 10: 37-43. 
23. Herbert V., Lau K.S., Gottlieb C.W., Bleicher S.J. Coated charcoal immunoassay of insulin. J. Clin. Endocrinol. Metab, 1965; 25: 1375-1384.

24. Hutton J.C., Malaisse W.J. Dynamics of $\mathrm{O}_{2}$ consumption in rat pancreatic islets. Diabetologia, 1980; 18: 395-405.

25. Janjic D., Andereggen E., Deng S. e. a. Improved insulin secretion of cryopreserved human islets by antioxidant treatment. Pancreas, 1996; 13: 166-172.

26. Juntti-Berggren L., Arkhammar P., Nilsson T. e. a. Glucose-induced increase in cytoplasmic $\mathrm{pH}$ in pancreatic beta-cells is mediated by $\mathrm{Na}^{+} / \mathrm{H}^{+}$exchange, an effect not dependent on protein kinase C. J. Biol. Chem, 1991; 266: 2353723541.

27. Kakei M., Kelly R.P., Ashcroft S.J., Ashcroft F.M. The ATP-sensitivity of $\mathrm{K}^{+}$channels in rat pancreatic B-cells is modulated by ADP. FEBS Lett, 1986; 208: 63-66.

28. Krippeit-Drews P., Backer M., Dufer M., Drews G. Phosphocreatine as a determinant of K(ATP) channel activity in pancreatic beta-cells. Pflugers Arch, 2003; 445: 556-562.

29. Larsson O., Ammala C., Bokvist K. e. a. Stimulation of the KATP channel by ADP and diazoxide requires nucleotide hydrolysis in mouse pancreatic beta-cells. $\mathbf{J}$. Physiol, 1993; 463: 349-365.

30. Larsson O., Deeney J.T., Branstrom R. e. a. Activation of the ATP-sensitive $\mathrm{K}^{+}$ channel by long chain acyl-CoA. A role in modulation of pancreatic beta-cell glucose sensitivity. J. Biol. Chem, 1996; 271: 10623-10626.

31. Li C., Buettger C., Kwagh J. e. a. A signaling role of glutamine in insulin secretion. J. Biol. Chem, 2004; 279: 13393-13401.

32. Li C., Najafi H., Daikhin Y. e. a. Regulation of leucine-stimulated insulin secretion and glutamine metabolism in isolated rat islets. J. Biol. Chem, 2003; 278: 2853-2858.

33. Lowry O.H., Rosebrough N.J., Farr A.L., Randall R.J. Protein measurement with the Folin phenol reagent. J. Biol. Chem, 1951; 193: 265-275.

34. Lu D., Mulder H., Zhao P. e. a. 13C NMR isotopomer analysis reveals a connection between pyruvate cycling and glucose-stimulated insulin secretion (GSIS). Proc. Natl. Acad. Sci. USA, 2002; 99: 2708-2713.

35. MacDonald M.J., Fahien L.A. Glutamate is not a messenger in insulin secretion. J. Biol. Chem, 2000; 275: 34025-34027.

36. Maechler P., Wollheim C.B. Mitochondrial glutamate acts as a messenger in glucose-induced insulin exocytosis. Nature, 1999; 402: 685-689.

37. Malaisse W.J., Sener A., Carpinelli A.R. e. a. The stimulus-secretion coupling of glucose-induced insulin release. XLVI. Physiological role of L-glutamine as a fuel for pancreatic islets. Mol. Cell. Endocrinol, 1980; 20: 171-189.

38. Michalik M., Nelson J., Erecinska M. Glutamate production in islets of Langerhans: properties of phosphate-activated glutaminase. Metabolism, 1992; 41: 13191326.

39. Misler S., Gillis K., Tabcharani J. Modulation of gating of a metabolically regulated, ATP-dependent $\mathrm{K}^{+}$channel by intracellular $\mathrm{pH}$ in $\beta$-cells of the pancreatic islet. J. Membr. Biol, 1989; 109: 135-143.

40. Panten U., Zielmann S., Langer J. e. a. Regulation of insulin secretion by energy metabolism in pancreatic $\beta$-cell mitochondria. Studies with a non-metabolizable leucine analogue. Biochem. J, 1984; 219: 189-196.

41. Prentki M., Matschinsky F.M. $\mathrm{Ca}^{2+}$, cAMP, and phospholipid-derived messengers in coupling mechanisms of insulin secretion. Physiol. Rev, 1987; 67: 11851248. 
42. Ronner P., Naumann C.M., Friel E. Effects of glucose and amino acids on free ADP in betaHC9 insulin-secreting cells. Diabetes, 2001; 50: 291-300.

43. Rosario L.M., Rojas E. Modulation of $\mathrm{K}^{+}$conductance by intracellular $\mathrm{pH}$ in pancreatic beta-cells. FEBS Lett, 1986; 200: 203-209.

44. Rutter G.A. Nutrient-secretion coupling in the pancreatic islet beta-cell: recent advances. Mol. Aspects. Med, 2001; 22: 247-284.

45. Sato Y., Aizawa T., Komatsu M. e. a. Dual functional role of membrane depolarization/ $\mathrm{Ca}^{2+}$ influx in rat pancreatic $\beta$-cell. Diabetes, 1992; 41: 438-443.

46. Schulze D., Rapedius M., Krauter T., Baukrowitz T. Long-chain acyl-CoA esters and phosphatidylinositol phosphates modulate ATP inhibition of KATP channels by the same mechanism. J. Physiol, 2003; 552: 357-367.

47. Sener A., Conget I., Rasschaert J. e. a. Insulinotropic action of glutamic acid dimethyl ester. Am. J. Physiol, 1994; 267: E573-584.

48. Sener A., Malaisse-Lagae F., Malaisse W.J. Stimulation of pancreatic islet metabolism and insulin release by a nonmetabolizable amino acid. Proc. Natl. Acad. Sci. USA, 1981; 78: 5460-5464.

49. Sener A., Malaisse W.J. L-leucine and a nonmetabolized analogue activate pancreatic islet glutamate dehydrogenase. Nature, 1980; 288: 187-189.

50. Seo Y., Murakami M., Watari H. e. a. Intracellular $\mathrm{pH}$ determination by a 31PNMR technique. The second dissociation constant of phosphoric acid in a biological system. J. Biochem. (Tokyo), 1983; 94: 729-734.

51. Shepherd R.M., Henquin J.C. The role of metabolism, cytoplasmic $\mathrm{Ca}^{2+}$, and $\mathrm{pH}$-regulating exchangers in glucose-induced rise of cytoplasmic $\mathrm{pH}$ in normal mouse pancreatic islets. J. Biol. Chem, 1995; 270: 7915-7921.

52. Stiernet P., Guiot Y., Gilon P., Henquin J.C. Glucose acutely decreases $\mathrm{pH}$ of secretory granules in mouse pancreatic islets. Mechanisms and influence on insulin secretion. J. Biol. Chem, 2006; 281: 22142-22151.

53. Tanaka A., Chance B., Quistorff B. A possible role of inorganic phosphate as a regulator of oxidative phosphorylation in combined urea synthesis and gluconeogenesis in perfused rat liver. A phosphorus magnetic resonance spectroscopy study. J. Biol. Chem, 1989; 264: 10034-10040.

54. Tarasov A., Dusonchet J., Ashcroft F. Metabolic regulation of the pancreatic beta-cell ATP-sensitive $\mathrm{K}^{+}$channel: a pas de deux. Diabetes, 2004; 53 Suppl 3: S113-122.

55. Tian Y., Laychock S.G. Protein kinase $\mathrm{C}$ and calcium regulation of adenylyl cyclase in isolated rat pancreatic islets. Diabetes, 2001; 50: 2505-2513.

56. Wesslen N., Bergsten P., Hellman B. Glucose-induced reduction of the sodium content in beta-cell-rich pancreatic islets. Biosci. Rep, 1986; 6: 967-972. 